\title{
Influence of Leadership Behavior Attributes on Work-Related Lecturer's Attitudes
}

\author{
Khoirotul IDAWATI ${ }^{*}$, Hanifudin MAHADUN² \\ 1,2Lecturer, Dr. Universitas Hasyim Asyari, Tebuireng Jombang, Jawa Timur, Indonesia. \\ Email: laraiba.supercamp@gmail.com \\ * Corresponding Author
}

\begin{abstract}
Received: 18.07.2021 Accepted: 10.10.2021 Published: 03.12.2021 DOI: 10.47750/QAS/22.185.02
\end{abstract}
\begin{abstract}
This study explores the direct and indirect effects of leadership style and lecturer performance on burnout and job satisfaction. Specifically, it examines the burnout effect on job satisfaction and investigates its role as a mediator of the influence of leadership style on lecturer performance. Furthermore, the study explains the relationship between variables and the mediation effect using a sample of 110 randomly chosen lecturers at a private Islamic university in East Java. SMART-PLS was used for data analysis and to explain the relationship between variables. The results show that leadership style has no direct effect on lecturer performance but negatively affects burnout.

Moreover, leadership style positively affects lecturer performance, while burnout negatively impacts job satisfaction, which mediates the leadership style influence on lecturer performance. This finding confirms that job satisfaction is an essential mediator in the impact of leadership style on lecturer performance improvement. Furthermore, it contributes to the literature on leadership style and its impact on work-related attitudes for further study development.
\end{abstract}

Keywords: Leadership, Behavioral Leadership Style, Job Burnout, Job Satisfaction, Lecturer Performance.

\section{Introduction}

Education development increases with intense competition, making human resources essential in maintaining the organization's competitive advantage. However, diversity of background, education, and experience would increase competence when appropriately managed by the leadership (Rahmi et al., 2020). Therefore, educational institutions and educators play a crucial role in ensuring that individuals possess the typical characteristics. The ongoing reforms imply that lecturer quality is key to improving education (Benoliel \& Barth, 2017). Lecturer qualifications are among the factors directly affecting education efficiency because it influences the behaviour expected of students (Aydemir \& Kalin, 2021). Lecturers have a substantial role in handling activities related to university operations.

The organization's educational progress and development are determined by the lecturers' and lecturers' performance. They are passionate about their work depending on the leadership behaviour model. Leadership is the spirit that drives the university to achieve its goals. Leadership must encourage the performance of lecturers and other education staff optimally through various processes of mentoring, coaching, supervision, evaluation and selection of lecturers and education staff (Hidayat \& Wulandari, 2020). Thien (2019) stated that the leadership model distributes its authority to lecturers affects their academic optimism and commitment to the organization.

The pandemic has caused significant changes in communication facilitated by technological advances. People are driven to media applications that allow direct connection and interaction between individuals, institutions, companies, and even countries through telecommunications. Distance education has been promoted to address the problems associated with geographic distance and the many reasons that prevent hands-on learning and face-to-face classes, such as a pandemic (Kim, 2020; Bautista et al., 2021). This is sometimes referred to as e-learning or online learning. This type of institutional-based formal education in which students, resources, and instructors use interactive telecommunications systems to connect (Kim, 2020). Distance education can be asynchronous, where learning takes place where students can choose when to participate in learning using a variety of tools or synchronization. This is where learning happens using live video feeds (like Zoom, Google Meet, or Discord) with live feedback from students and lecturers (Kim, 2020).

This new environment allows flexible and self-paced learning and reflection, which gives the students ample time to review the learning materials and improve the lesson activities, and at the same time, allow the lecturers to monitor the students' progress along the process (Rapanta et al., 2020). However, the abrupt shift to digital learning has led to a significant increase in the lecturers' tasks, including the preparation of lectures, tutorials, laboratory works, and assessment tools (Dietrich et al., 2020).

The impact of online learning shown is very timeconsuming and draining, especially for senior lecturers. However, the intense shift to telecommunications increases stress and fatigue due to the increased screen time. Fatigue is a syndrome conceptualized as a result of unprecedented and 
unsuccessfully managed chronic work stress. As a result, the excessive workload could be one of the factors in the emergence of burnout (Bosak et al., 2021). Burnout is a psychological and pathological syndrome of emotional exhaustion due to one's work.

Furthermore, it is related to depersonalization (impersonal response to one's service recipients) and dissatisfaction with the personal work accomplishments (Okpozo et al., 2017; Maslach et al., 2001). Okpozo et al. (2017) stated that when the assignment is excessively continuous, it causes burnout in an empowered person, with the overload from physical and mental fatigue, resulting in stress accumulation. Burnout became the focus of our research for several reasons. First, harming burnout's effect on employees may involve high costs due to turnover, absenteeism, and decreased productivity. Second, an understanding of burnout's role can help guide leaders in reducing its harmful effects. Third, burnout studies are related to attitudes and behaviours, which are crucial in performance (Chen \& Chen, 2018).

University, excellence ranking system causes academic staff to increase related stress. This has a significant impact on academics employee attitudes related to work. Therefore, $\mathrm{HEI}$ needs to take advantage of its high-performance employees and protect them from increasing stress levels, staff welfare, organizational performance and competitiveness, and intellectual health of a nation. In addition, academic employees must be nurturing, knowledgeable and competent enough to deal with pressures when faced with challenges and environmental change. HEls must respect how to balance their work attitudes and stress to create outstanding academic employees (Karia \& Asaari, 2019, Mirici \& Sari, 2021).

Increasingly competitive demands make organizations strive to maintain and increase individual and organizational performance. Most have taken strategic steps to help employees avoid or overcome health-related problems, such as burnout (Kuruüzüm et al., 2008, Gill et al., 2006). According to Dias \& Angelico (2018), Giorgi et al. (2017), and Katau et al. (2021), employees with heavier tasks and higher work demands have a high risk of burnout. Similarly, this applies to the demands to improve the performance and academic reputation of lecturers and institutions. However, lecturers still have to carry out the tri dharma of the university to meet the BKD's requirements. Therefore, a leadership style that offers practical solutions to overcome work saturation is needed. Chen \& Chen (2018) found a relationship between leadership style on stress levels and employee burnout when the leader behaviour is inappropriate with their expectations. Moreover, Tepper (2000) showed how managers treat their staff, increasing job stress and negatively affecting leadership style and burnout.

Previous research has shown that leadership, burnout, and job satisfaction have effects impact on performance (Gilbert et al., 2017), Okpozo et al. (2017), Ugaddan \& Park (2017). Although employee leadership plays an essential role in the $\mathrm{HEI}$ environment, the evolution of leadership attributes towards work-related attitudes has not been well explored and defined. As a result, research on leadership attributes and Employee attitudes regarding work contain limited and immature observations. Therefore, This paper explores and attempts to understand the evolution of leadership attributes and such a role in encouraging work-related attitudes (Karia \& Asaari, 2019).

There is a research gap on leadership and work-related attitudes. First, traditional research focuses on leadership as a factor for influencing others or the social influence of superiors on subordinates (Karia \& Asaari, 2019), which leads to an increase in organizational performance but ignores the work- life of employees. This contemporary study recognizes the urgency for new leadership models in rapidly evolving technology and a dynamic environment to enhance workrelated attitudes. Second, little is known because most leadership research concentrates on organizational context (Andert et al., 2011). Almost none research on leadership complexities and attributes embedded in non-replicable and non-substitutable employees to predict work-related employees attitudes and academic employees at $\mathrm{HEI}$ in particular. Thus, studies need to understand leadership attributes that anticipate employee job-related attitudes, such as job satisfaction and employee performance (Karia \& Asaari, 2019).

The absence of knowledge about leadership complexity and embedded attributes on employees and their effect on work-related attitudes provides opportunities for learning to acknowledge the new leadership model's new findings. By conquering employee views, This study examines the emergence of leadership attributes and then examines the extent to which these attributes encourage work-related attitudes among academic employees on HEl. This new contribution explains how $\mathrm{HEl}$ and its leaders (organizations and managers) can develop work-related attitudes and achieve high-performing employees through the attributes of leadership in the industrial era 4.0, rapid technological advances and a dynamic environment; and why organizations need to be aware of the attitudes of their employees towards their working life.

This study shows a leadership style as shared decision making, allowing subordinates to express their opinions, and producing positive effects, including increased lecturer motivation and performance (De Nobile et al., 2013; Benoliel \& Barth, 2017). Theories about leadership and performance have many similarities, so it has many contradictions and variables inconsistency which can influence the conclusions. This study is critical to understand human behaviour and its impact on performance. The leader encourages subordinates to come up with new ideas and creative solutions to the problems faced. Therefore, subordinates are genuinely involved and empowered in problem formulation and solution finding (Pratiwi \& Widodo, 2021). However, some studies have focused on the relationship between leadership style and burnout in organizations. Gilbert et al. (2017), Okpozo et al. (2017) showed that leadership negatively impacts burnout Similarly, Kelloway \& Barling (2010); Skakon et al. (2010) stated that leadership style could improve well-being and prevent workplace stress. Furthermore, recent studies have shown that it could cause stress and tension resulting in lecturer burnout and job satisfaction.

Several studies have found the effect of contrasting leadership on performance in public services in developing countries. According to Bosak et al. (2021), this contrasting leadership could improve performance. Additionally, Han et al. (2021) stated that task-and relationship-oriented leadership positively affected team performance. Garg \& Ramjee (2013) stated its effect on performance is indirect and determined by employee satisfaction at work (Kumasey, Bawole, Hossain, 2017; Peng, Liao, Sun, 2019). Job satisfaction results from employees' perceptions of how their work provides everything necessary (Luthans, 2011). Performance is the evaluation result of the work based on the aforementioned criteria (Robbins \& Judge, 2011). Moreover, Donkor \& Dongmei (2020) suggested that public-sector leadership adopt a strategy to increase commitment in organizational activities to improve employee performance. The top leaders should continuously encourage innovative and productive work to improve performance. 
This study explores the direct or indirect relationship between leadership style and lecturer performance due to its importance in improving organizational performance. It was conducted on the leadership style of higher education institutions in East Java, based on five questions. The first question was whether leadership style could improve lecturer performance. The second question investigated whether leadership style affects burnout. Third, the study explored whether leadership style increases job satisfaction. The fourth question was whether burnout affects job satisfaction. Fifth, this study examined the mediation role of job satisfaction in influencing leadership style on lecturer performance.

\section{Literature Review}

\subsection{Leadership}

According to Marion \& Gonzales (2014), leadership is the person who tell someone, evaluate and influencing people to achieve organizational goals. This definition means that leadership is a relational concept existing only in relationships with other people (followers). It is a process that should persuade others to take action.

Hersey \& Blanchard (1992) developed a model using the term task behaviour to describe the organization and definition of the roles of group followers. Moreover, it explains member activities, when, where, and how to solve them, and establishes organizational patterns and communication channels. The model also shows how to complete work and the leadership that fosters personal relationships by opening communication channels and providing socio-emotional support. Donkor \& Dongmei (2020) stated that leadership could improve performance. The essence of behavioural leadership is the sharing of power involving subordinates to make changes. By applying various managerial practices, leaders can empower their subordinates to become more confident in their abilities. With a stronger sense of selfefficacy, subordinates will succeed in the conduct of various challenging tasks. Behavioural leadership is proposed to complete the existing leadership style based on developing science with a leadership behaviour pattern.

Moreover, intellectually able to translate it into productive performance. Furthermore, Han et al. (2021) stated that task and relationship oriented leadership positively affects team performance. Therefore, the hypothesis is:

H1 Leadership style positively affects lecturer performance

\subsection{Burnout}

Burnout has been linked to impaired job performance, poor mental and physical health, and worsening relationships with family and friends (Becker et al., 2006). Additionally, stressrelated symptoms, increased anxiety risk, depression, and reduced self-esteem are adverse physical and mental health outcomes related to fatigue (Maslach et al., 2001). Burnout workers experience mental fatigue, loss of commitment, emotional exhaustion, and decreased job satisfaction (Bhanugopan \& Alan, 2006). Employee fatigue could cause organizational and individual losses because it harms work results, such as job dissatisfaction (Ybema et al., 2010; Chen \& Chen, 2018).

Burnout is a combination of three psychic tendencies, including emotional exhaustion, indifference to career and self (depersonalization), and decreased individual achievement (personal accomplishment) (Maslach et al., 2001). Emotional exhaustion is a burnout indicator marked by loss of feeling and attention, trust, interest, and enthusiasm. People experiencing emotional exhaustion feel an emptiness in their life, tired, and unable to cope with their work demands.

Diminished personal accomplishment is a lack of selfactualization, low work motivation, and decreased selfconfidence. This condition is often seen in low achievement (Maslach et al., 2001). Depersonalization is the development of a cynical attitude towards one's career and performance (Maslach et al., 2001). A person with depersonalization problems feels that none of their activities has value or meaning. This attitude is shown through ignorance, being cynical, heartless, and having no concern for others. In line with this, Gilbert et al. (2017) and Okpozo et al. (2017) showed the leadership's negative effect on burnout.

Therefore, the proposed hypothesis is:

H2 Leadership style negatively impacts burnout.

\subsection{Job Satisfaction}

Luthans (2011) defined job satisfaction as the result of employees' perceptions of how their work provides everything considered necessary. Robbins \& Judge (2011) stated it is the general attitude of individuals to their work. A person with high satisfaction indicates a positive attitude instead of a dissatisfied individual with a negative attitude.

Job satisfaction indicators could be divided into three categories. The first category comprises skill diversity, task and objection, autonomy, and feedback. Second, organizational characteristics include the business scale, complexity, formalization, and centralization. It encompasses the number of group members and their budget, operation duration, and age of the working group. Third, individual characteristics include gender, education level, age, years of service, marital status, and the number of dependents. Job satisfaction could improve employee performance in a common understanding of the leadership function in achieving organizational goals (Ugaddan \& Park, 2017). One of the functions is allowing lecturers to carry out the tri dharma (Asaari, Dwiedi, Lawton, 2013; Audenaert et al., 2016; Karia \& Assari, 2019).

Their satisfaction determines the influence of leadership style on employee performance at work (Kumasey, Bawole, Hossain, 2017; Peng, Liao, Sun, 2019). As for leadership, it is viewed as a process of social interaction where the leaders demonstrate an ability to impact their followers' behaviours and strongly influence the subordinates performance outcomes. The leadership effectiveness perceived by the followers within a work unit may thus be regarded as a work unit climate. When subordinates perceive their supervisor as effective in terms of leadership, it can provide a psychological climate to mitigate the stress due to job demands and job resources. However, the perception of ineffective leadership behaviour may exacerbate employees burnout (Chen \& Chen, 2018). Therefore, the proposed hypothesis is:

H3 Leadership style increases job satisfaction

H4 Burnout negatively impacts job satisfaction

\subsection{Performance}

Robbins \& Judge (2011) stated that performance evaluates the work carried out based on the previous criteria. In line with this, Bernardi \& Russel (1993) suggested six factors or indicators affecting performance. These are work quantity, quality, timeliness, effectiveness, need for supervisors, and good relations with other employees. Moreover, Audenaert et al. (2016) defined performance as the work result based on quantity, quality, and the employees' direct or indirect contribution to the organization's goals. It is seen as task and contextual performance (Mensah, 2015). 


\section{GENERAL MANAGEMENT}

Task performance is considered a core job task specified in the job description (Kiyani et al., 2016). Contextual performance is a pattern of social and psychological behaviour at work that performs tasks with full responsibility and exceed the company's standards (Mensah, 2015)

Previous studies identified leadership as a factor that increases job satisfaction (Benoliel \& Barth, 2017). However, although the relationship between leadership and job satisfaction has received significant attention, the findings are still mixed (Benoliel \& Barth, 2017). Many studies suggested that leadership styles need to increase employee satisfaction. In line with this, Mardanov (2021) stated that performance is much higher when an employee is delighted with their job. Therefore, the proposed hypothesis is:

$\mathrm{H} 5$ Job satisfaction mediates the influence of leadership style on lecturer performance.

\section{Research Methodology}

\subsection{Research Design}

This study uses a correlational survey research design to explore the relationship between previously defined variables (Aydemir \& Kalin 2021). Additionally, it explains the relationship between variables and makes predictions based on the results (Aydemir \& Kalin 2021). This research was designed with a quantitative approach, involving direct and mediationrelationships. It analyzed the relationship between leadership style, job satisfaction, and lecturer performance. Data were collected using questionnaires distributed to 110 private Islamic university lecturers in East Java, selected through Sensus sampling.

\subsection{Data Collection and Research Instruments}

Quistionnaire was used to collect data distributed to all respondents. The leadership style adopts the opinion of Hersey \& Blanchard (1992), which used the term task behaviour to describe the organization and definition of the group members' roles (followers). Hersey \& Blanchard (1992) explained member activities, when, where, and how to solve them, and established organizational patterns and communication channels. Furthermore, it showed how work is completed and the leadership that fosters personal relationships with followers by opening communication channels and providing socio-emotional support.
Okpozo et al. (2017); Maslach et al. (2001) classified burnout into three indicators. These include emotional exhaustion because of work, depersonalization (impersonal response to service recipients), and reduced personal achievement (less satisfaction with work results).

Job satisfaction indicators comprised three characteristics adopted from Glisson \& Durick (1988). First, job characteristics are skill diversity, task identity and objection, autonomy, and feedback. Second, organization characteristics include the business scale, complexity, formalization, centralization, number, and budget of group members, operation duration, and age of the working group. Third, individual characteristics include gender, education level, age, service years, marital status, and the number of dependents.

Performance indicators include quantity, quality, punctuality, attendance, and ability to work together, adopted from Mathis \& Jackson (2012). The variable measurement scale used is the Likert, weighted according to items 1 to 5 (Sekaran, 2003).

\subsection{Data Analysis}

Data were analyzed using PLS to test the modified results of several research models to provide an overview of the variables studied. This analysis method was used because the available indicators do not meet the reflective measurement model (Garson, 2016). The scale used is Likert ( $1=$ Strongly disagree $-5=$ Strongly agree). Analysis using Smart-PLS 3.0. The criteria for measuring variables and constructs are based on conditions AVE values > 0.50 (Hair et al., 2014). Composite Reliability Value $(C R>0.6)$. Measurement of Cronbach's alpha value $>0.5, \mathrm{R}$-square, and loading-factor as the main forming variable (Chin, 1998; Supriyanto et al., 2020 ).

\section{Results And Discussions}

\subsection{Statistical Calculation Results}

This study tests the relationship between variables using SMART-PLS, measurement, and structural equation model. The reliability test results are leadership style, burnout, job satisfaction, and performance, whose Cronbach alpha value was higher than the cut-off point of 0.60 . Therefore, all variables are accepted internally because it is higher than > 0.60 (Hair et al., 2014). The composite reliability results are good when the value is above 0.70 , as presented in Table 1.

\begin{tabular}{|l|l|l|l|}
\hline Variables & Alpha Cronbach & Composite Reliability & Conclusion \\
\hline Leadership style & 0.612 & 0.836 & Reliable \\
\hline Burnout & 0.736 & 0.849 & Reliable \\
\hline Work satisfaction & 0.759 & 0.861 & Reliable \\
\hline performance & 0.881 & 0.913 & Reliable \\
\hline
\end{tabular}

Table 1: Instrument Reliability Test Results

\begin{tabular}{|c|c|c|c|c|c|c|}
\hline \multirow{2}{*}{$\begin{array}{l}\text { Research } \\
\text { Variable }\end{array}$} & \multirow[t]{2}{*}{ AVE } & \multirow[t]{2}{*}{$\sqrt{\text { AVE }}$} & \multicolumn{4}{|c|}{ Correlations of the latent variables } \\
\hline & & & B & $\mathbf{L}$ & $\mathbf{P}$ & WS \\
\hline B & 0.653005 & 0.808087 & 1.000000 & & & \\
\hline $\mathbf{L}$ & 0.718641 & 0.847727 & 0.735044 & 1.000000 & & \\
\hline $\mathbf{P}$ & 0.677171 & 0.823231 & 0.785193 & 0.797175 & 1.000000 & \\
\hline WS & 0.675610 & 0.821954 & 0.806055 & 0.785685 & 0.806628 & 1.000000 \\
\hline
\end{tabular}

Table 2: The value of AVE, $\sqrt{ } A V E$, and correlation between latent variables 


\section{GENERAL MANAGEMENT}

Table 2 shows that the square root of the average variance extracted ( $\sqrt{ }$ AVE) value of all variables is greater than the correlation between latent variables, which is valid.

\subsection{Structural Equation Modeling}

The direct effect results in Table 3 indicate leadership style does not directly influence lecturer performance, with a path coefficient $=0.236$ and $p=0.101$, meaning that hypothesis 1 is rejected. Also, it negatively affects burnout, with a path coefficient $=-0.735$ and $p=0.000$, indicating that hypothesis 2 is accepted. The affects of leadership style on job satisfaction was positive and significant, with a path coefficient $=0.369$ and $p=0.015$, suggesting that hypothesis 3 is accepted. Furthermore, the effect of burnout on job satisfaction was negative and significant, with a path coefficient $=-0.567$ and $p$ $=0.000$, showing that hypothesis 4 is accepted.

\begin{tabular}{|l|l|l|l|l|l|}
\hline \multicolumn{2}{|l|}{ Variable Relationship } & Path Coefficient & t statistics & p-value & Conclusion \\
\hline L & P & 0.236 & 1.654 & 0.101 & Non-sig \\
\hline L & B & -0.735 & -8.518 & 0.000 & Significant \\
\hline L & WS & 0.369 & 2.463 & 0.015 & Significant \\
\hline B & WS & -0.567 & -4.374 & 0.000 & Significant \\
\hline WS & P & 0.714 & 5.427 & 0.000 & Significant \\
\hline
\end{tabular}

Table 3: Direct Effect Hypothesis Testing Results

\subsection{Mediation Effect}

The mediation hypothesis was tested to detect the position of the intervening variable in the model. The Sobel Test was carried out using the free Sobel test calculator software for the significance of mediation version 4.0. Table 4 presents the Sobel Test analysis results.

\begin{tabular}{|l|l|l|l|l|l|l|l|}
\hline Path & A & B & SEA & SEB & t count & sig & Conclusion \\
\hline L-WS-P & 0.369 & 0.714 & 0.149 & 0.132 & 2.252 & 0.024 & sig \\
\hline
\end{tabular}

Table 4: Sobel Test Result

Based on Table 4, the Sobel Test value was 2.252> 1.96, and the significance was $0.024<0.05$. This means that job satisfaction mediates the effect of leadership style on lecturer performance (H5 is accepted). Furthermore, an examination method (Ekowati et al., 2017) was used to determine the nature of the relationship between variables as a complete, partial, or non-meditating variable. In this case, it is a complete mediation variable when (c) and (d) are significant but (a) are not significant. When (c), (d), and (a) are significant, and the coefficient of $(a)$ is smaller than (b), it is considered a partial mediation variable. However, when the coefficient of (a) is almost the same as (b), then it is not a mediation variable. When (c) and (d) are not significant, it is a mediation variable (Ekowati et al., 2017). The results of testing the coefficients are in Table 5.

\begin{tabular}{|l|l|l|l|l|l|l|l|}
\hline \multicolumn{2}{|l|}{ Effect of mediating variable } & \multicolumn{2}{l|}{ Path Coefficient } & $\begin{array}{l}\text { Mediation } \\
\text { Nature }\end{array}$ & Conclusion \\
\hline Exogenous & Mediation & Endogenous & c & d & a & & \\
\hline $\begin{array}{l}\text { Leadership } \\
\text { style }\end{array}$ & Job & performance & 0.369 & $\begin{array}{l}0.714 \\
\text { (S) }\end{array}$ & $\begin{array}{l}0.236 \\
\text { (NS) }\end{array}$ & complete & significant \\
\hline
\end{tabular}

Table 5: Path Coefficient of Mediation Effect and Hypothesis Testing

The results showed that leadership style could not directly improve the lecturers' performance because other factors, such as job satisfaction, affected it. This is especially in private universities where satisfaction through compensation impacts performance. Garg \& Ramjee (2013) supported it, which stated that leadership style indirectly affects performance. Therefore, factors supporting performance, including the leader, should increase commitment in organizational activities to improve employee performance. Furthermore, they should keep working innovatively and productively to improve performance (Donkor \& Dongmei (2020).

A better leadership style reduces the lecturer work saturation level in line with Gilbert et al. (2017), Okpozo et al. (2017), Chen \& Chen (2018) which stated that leadership negatively impacts burnout. Therefore, the right leadership style increases well-being and prevents psychological and work-related stress (Kelloway \& Barling, 2010; Skakon et al., 2010). This supports Dias \& Angelico (2018) and Giorgi et al. (2017), which stated that employees with heavier tasks and higher job demands experience work boredom. Moreover, job characteristics, excessive workload, role conflict, and ambiguous roles influence burnout. This condition is more pronounced in private universities with demands for lecturer workloads and the international reputation to be met. Katou et al. (2021) showed that various efforts are needed to reduce burnout and increase job satisfaction, such as the right leadership style.

Leadership style could increase lecturer job satisfaction. Peng, Liao, Sun (2019) revealed that it is positively correlated with job satisfaction. In this case, job satisfaction could be increased by a leadership style manifested in the decisionmaking process (Benoliel \& Barth, 2017). The findings show that lecturers at Islamic universities in East Java have great leadership attributes with job and career satisfaction. These attributes may be needed to increase the efficiency and effectiveness of higher education institutions.

Moreover, they have innovative leadership that could design research, publications, teaching, and activities related 
to the tri dharma of higher education. They could also work independently with their expertise in education and teaching, research, publications, and academic consulting (Asaari, Dwiedi, Lawton, 2013; Karia \& Assari, 2019). Lecturers with behavioural leadership are more satisfied with their jobs when trusted to work independently in teaching, service, research consulting, and academic services (Audenaert et al., 2016; Karia \& Assari, 2019).

Burnout negatively impacts job satisfaction, meaning that better job satisfaction reduces the lecturer's boredom level. The results are consistent with (Ybema et al., 2010; Chen \& Chen, 2018), which showed that burnout negatively affects job satisfaction. Additionally, this reinforces Bhanugopan \& Alan (2006), which found that fatigued employees experience commitment loss, emotional exhaustion, and decreased job satisfaction over time. Similar conditions were expressed by Okpozo et al. (2017) that burnout is a psychological and pathological syndrome of emotional exhaustion, depersonalization, and dissatisfaction with personal achievements. Furthermore, symptoms related to stress increased the risk of anxiety, depression, and lack of selfconfidence result from burnout (Maslach et al., 2001).

Job satisfaction mediates the effects of leadership style on lecturer performance. Peng, Liao, Sun (2019) stated that the influence is determined by employee satisfaction at work. Moreover, Ugaddan \& Park (2017) stated that job satisfaction improves performance in a common understanding of the leadership function in achieving organizational goals. Similarly, Donkor \& Dongmei (2020) showed that performance improvement requires a leader willing to adopt a strategy to increase job satisfaction. Therefore, top leaders should continue to motivate to keep working innovatively and productively to improve performance. Furthermore, leadership should create a conducive work environment and support their subordinates to cope with stressful routines and unexpected situations (Chen \& Chen 2018).

\section{Conclusion}

Leadership does not affect performance. Performance is indirect and determined by employee satisfaction at work Job satisfaction results from employees' perceptions of how their work provides everything necessary.

\section{References}

[1] Andert, D., Platt, A., \& Alexakis, G. (2011). Alternative, Grassroots, And Rogue Leadership: A Case For Alternating Leaders In Organizations. Journal of Applied Business Research (JABR), 27(2). doi:10.19030/jabr.v27i2.4139

[2] Asaari, M.H.A.H., Dwiedi, A., Lawton, A. and Karia, N. (2013). Academic leadership and work-related attitude: genders, ethnics and academic ranks of faculty members in Malaysian public universities. Cambridge Business \& Economics Conference, Oxford, 1-24.

[3] Audenaert, M., Decramer, A., Lange, T., \& Vanderstraeten, A. (2016). Setting high expectations is not enough. International Journal of Manpower, 37(6), 1024-1041. doi:10.1108/ijm-122015-0201

[4] AYDEMIR, A., \& ULU KALIN, Ö. (2021). Relationship between Levels of Intercultural Sensitivity and Emotional Intelligence amongst Preservice Social Studies Teachers. Review of International Geographical Education Online. doi:10.33403/rigeo. 759860

[5] Bautista, A. P., Bleza, D. G., Buhain, C. B., \& Balibrea, D. M.
Leadership style negatively impacts burnout. As for leadership, it is viewed as a process of social interaction where the leaders demonstrate an ability to impact their followers' behaviours and strongly influence the subordinates performance outcomes. When subordinates perceive their supervisor as effective in terms of leadership, it can provide a psychological climate to mitigate the stress due to job demands and job resources. However, the perception of ineffective leadership behaviour may exacerbate employees burnout.

Leadership style could increase lecturer job satisfaction. Job satisfaction could be increased by a leadership style manifested in the decision-making process.

Burnout can reduce job satisfaction. Burnout is an accumulated reaction to chronic stress experienced by individuals who perform as service providers and constantly interact with others. Burnout is expensive for organizations and individuals, as it can lead to negative work-related outcomes such as job dissatisfaction.

Job satisfaction mediates the effects of leadership style on lecturer performance. The influence could not improve lecturer performance because it influenced by other factors, such as job satisfaction. Therefore, a better leadership style lowers lecturer's work saturation level, improves well-being, and prevents workplace stress. Consequently, it results in lecturers being more satisfied with their jobs and careers when trusted to work independently. Therefore, better satisfaction reduces the lecturer job saturation level. Fatigued workers experience a decrease in job satisfaction. The effect of leadership style on lecturer performance is mediated by job satisfaction. This implies that effective leadership reduces the impact of job demands on burnout and creates job satisfaction. Lecturers are required to work professionally and are trained to consider the workload demands. Moreover, when leaders demonstrate effective leadership techniques, lecturers feel a conducive work climate and support. The strong support helps them overcome work fatigue, increase job satisfaction, and improve performance, determined by their satisfaction.

Some suggestions are made in this study, which was conducted at an Islamic university in East Java. Future studies should expand the object to involve public and private Islamic universities in East Java to obtain more generalized findings.

(2021). School Support Received and the Challenges Encountered in Distance Learning Education by Filipino Teachers during the Covid-19 Pandemic. International Journal of Learning, Teaching and Educational Research, 20(6), 360-385. doi:10.26803/ijtter.20.6.19

[6] Bhanugopan, R., \& Fish, A. (2006). An empirical investigation of job burnout among expatriates. Personnel Review, 35(4), 449-468. doi:10.1108/00483480610670607

[7] Becker, J. L., Milad, M. P., \& Klock, S. C. (2006). Burnout, depression, and career satisfaction: Cross-sectional study of obstetrics and gynecology residents. American Journal of Obstetrics and Gynecology, 195(5), 1444-1449. doi:10.1016/j.ajog.2006.06.075

[8] Benoliel, P., \& Barth, A. (2017). The implications of the school's cultural attributes in the relationships between participative leadership and teacher job satisfaction and burnout. Journal of Educational Administration, 55(6), 640656. doi:10.1108/jea-10-2016-0116

[9] Bernardin, H. John \& Joyce E.A. Russell. (1993). Human Resource Management. Singapore: McGraw Hill Inc 
[10] Bosak, J., Kilroy, S., Chênevert, D., \& C Flood, P. (2021). Examining the role of transformational leadership and mission valence on burnout among hospital staff. Journal of Organizational Effectiveness: People and Performance, 8(2), 208-227. doi:10.1108/joepp-08-2020-0151

[11] Chen, S.-C., \& Chen, C.-F. (2018). Antecedents and consequences of nurses' burnout. Management Decision, 56(4), 777-792. doi:10.1108/md-10-2016-0694

[12] Chin, W. (1998). The partial least squares approach to structural equation modeling. Modern Methods for Business Research, 295(2), 295-336. https://doi.org/10.1016/j.aap.2008.12.010

[13] De Nobile, J., McCormick, J., \& Hoekman, K. (2013). Organizational communication and occupational stress in Australian Catholic primary schools. Journal of Educational Administration, 51(6), 744-767. doi:10.1108/jea-09-20110081

[14] Dias, F. S., \& Angélico, A. P. (2018). Burnout Syndrome in Bank Employees: A Literature Review. Temas Em Psicologia, 26(1), 31-46. doi:10.9788/tp2018.1-02en

[15] Dietrich, N., Kentheswaran, K., Ahmadi, A., Teychené, J., Bessière, Y., Alfenore, S., ... Hébrard, G. (2020). Attempts, Successes, and Failures of Distance Learning in the Time of COVID-19. Journal of Chemical Education, 97(9), 2448-2457. doi:10.1021/acs.jchemed.0c00717

[16] Donkor, F., \& Zhou, D. (2020). Organisational commitment influences on the relationship between transactional and laissez- faire leadership styles and employee performance in the Ghanaian public service environment. Journal of Psychology in Africa, 30(1), 30-36. doi:10.1080/14330237.2020.1712808

[17] Ekowati, V. M., Surachman., Sumiati., Sudiro, A. (2017). The effect of transformational leadership on organizational citizenship behavior mediated by job satisfaction and organizational commitment. International Journal of Economic Research 14(3), 205-218

[18] Garg, A. K., \& Ramjee, D. (2013). The Relationship Between Leadership Styles And Employee Commitment At A Parastatal Company In South Africa. International Business \& Economics Research Journal (IBER), 12(11), 1411. doi:10.19030/iber.v12i11.8180

[19] Garson, G. D. (2016). Partial least square: Regression and structural equations models. North Carolina State University, USA: School of public \& international affairs. Retrieved from https://www.smartpls.com/resources/ebook_on_pls-sem.pdf.

[20] Garg, A. K., \& Ramjee, D. (2013). The Relationship Between Leadership Styles And Employee Commitment At A Parastatal Company In South Africa. International Business \& Economics Research Journal (IBER), 12(11), 1411. doi:10.19030/iber.v12i11.8180

[21] Gill, A. S., Flaschner, A. B., \& Shachar, M. (2006). Mitigating stress and burnout by implementing transformationalleadership. International Journal of Contemporary Hospitality Management, 18(6), 469-481. doi:10.1108/09596110610681511

[22] Giorgi, G., Arcangeli, G., Perminiene, M., Lorini, C., ArizaMontes, A., Fiz-Perez, J., ... Mucci, N. (2017). Work-Related Stress in the Banking Sector: A Review of Incidence, Correlated Factors, and Major Consequences. Frontiers in Psychology, 8. doi:10.3389/fpsyg.2017.02166

[23] Glisson, C., \& Durick, M. (1988). Predictors of Job Satisfaction and Organizational Commitment in Human Service Organizations. Administrative Science Quarterly, 33(1), 61. doi:10.2307/2392855

[24] Han, J., Yoon, J., Choi, W., \& Hong, G. (2021). The effects of shared leadership on team performance. Leadership \& Organization Development Journal, 42(4), 593-605. doi:10.1108/lodj-01-2020-0023

[25] Henseler, J., Dijkstra, T. K., Sarstedt, M., Ringle, C. M.,
Diamantopoulos, A., Straub, D. W., ... Calantone, R. J. (2014). Common Beliefs and Reality About PLS. Organizational Research Methods, 17(2), 182-209. doi:10.1177/1094428114526928

[26] Hersey, P. \& Blanchard, K. H. (1992). Organizational Behavior Management: Utilization of Human Resources. Jakarta : Erlangga.

[27] Hidayat, N., \& Wulandari, F. (2020). THE IMPACT OF LEADERSHIP BEHAVIOR ON SCHOOL PERFORMANCE. Jurnal Cakrawala Pendidikan, 39(3), 493-506. doi:10.21831/cp.v39i3.31005

[28] Karia, N., \& Abu Hassan Asaari, M. H. (2019). Leadership attributes and their impact on work-related attitudes. International Journal of Productivity and Performance Management, 68(5), 903-919. doi:10.1108/ijppm-02-20180058

[29] Katou, A. A., Koupkas, M., \& Triantafillidou, E. (2021). Job demands-resources model, transformational leadership and organizational performance: a multilevel study. International Journal of Productivity and Performance Management, ahead-of-print(ahead-of-print). doi:10.1108/ijppm-06-20200342

[30] Kelloway, E. K., \& Barling, J. (2010). Leadership development as an intervention in occupational health psychology. Work \& Stress, 24(3), 260-279. doi:10.1080/02678373.2010.518441

[31] Kim, J. (2020). Learning and Teaching Online During Covid19: Experiences of Student Teachers in an Early Childhood Education Practicum. International Journal of Early Childhood, 52(2), 145-158. doi:10.1007/s13158-020-00272-6

[32] Kiyani, A. A., Ayupp, K., \& Rasool, S. (2018). Exploring the construct of task performance of academics in an Asian context. Evidence-Based HRM: a Global Forum for Empirical Scholarship, 6(1), 25-38. doi:10.1108/ebhrm-03-2016-0008

[33] Kumasey, A. S., Bawole, J. N., \& Hossain, F. (2016). Organizational commitment of public service employees in Ghana: do codes of ethics matter? International Review of Administrative Sciences, 83(1_suppl), 59-77. doi:10.1177/0020852316634447

[34] Kuruüzüm, A., Anafarta, N., \& Irmak, S. (2008). Predictors of burnout among middle managers in the Turkish hospitality industry. International Journal of Contemporary Hospitality Management, 20(2), doi: $10.1108 / 09596110810852168$

[35] Marion, R \& Gonzales, L.D. (2014). Leadership In Education. Organizational Theory for Practitioners. Unaited States. Waveland Press Inc.

[36] Luthans, F. (2011). Organizational Behavior. An Evidence Based Approach. Twelfth Edition. New York: McGraw - Hill International Edition.

[37] Mardanov, I. (2020). Intrinsic and extrinsic motivation, organizational context, employee contentment, job satisfaction, performance and intention to stay. EvidenceBased HRM: a Global Forum for Empirical Scholarship, 9(3), 223-240. doi:10.1108/ebhrm-02-2020-0018

[38] Maslach, C., Schaufeli, W. B., \& Leiter, M. P. (2001). Job Burnout. Annual Review of Psychology, 52(1), 397-422. doi:10.1146/annurev.psych.52.1.397

[39] Mathis, Robert L. and John H. Jackson. (2012). Human Resource Management, First Edition. Jakarta : Salemba Empat.

[40] Mensah, J. K. (2015). A "coalesced framework" of talent management and employee performance. International Journal of Productivity and Performance Management, 64(4), 544-566. doi:10.1108/ijppm-07-2014-0100

[41] Mirici, H. \& Sari, Ş. (2021). An investigation of interaction among willingness to communicate, academic achievement and 12- self guides. International Online Journal of Education andTeaching (IOJET), 8(2), 653-661.

[42] Okpozo, A. Z., Gong, T., Ennis, M. C., \& Adenuga, B. (2017). 


\section{GENERAL MANAGEMENT}

Investigating the impact of ethical leadership on aspects of burnout. Leadership \& Organization Development Journal, 38(8), 1128-1143. doi:10.1108/lodj-09-2016-0224

[43] Peng, S., Liao, Y., \& Sun, R. (2019). The Influence of Transformational Leadership on Employees' Affective Organizational Commitment in Public and Nonprofit Organizations: A Moderated Mediation Model. Public Personnel Management, 49(1), 29-56. doi:10.1177/0091026019835233

[44] Pratiwi, R \& Widodo. (2021). Coercive Intellectual Leadership Antecedent towards Organizational Performance. Quality access to Success, 22 (182), 35-40.

[45] Rahmi, E., Patoni, A., \& Sulistyorini, S. (2020). The Management of Human Resources Development in Increasing the Quality of Islamic Education Institutions. Al-Ta Lim Journal, 27(2), 166-178. doi:10.15548/jt.v27i2.624

[46] Rapanta, C., Botturi, L., Goodyear, P., Guàrdia, L., \& Koole, M. (2020). Online University Teaching During and After the Covid-19 Crisis: Refocusing Teacher Presence and Learning Activity. Postdigital Science and Education, 2(3), 923-945. doi:10.1007/s42438-020-00155-y

[47] Robbins, S. P., \& Judge, T. A. (2011). Organizational Behavior. New Jersey: Pearson education. Inc.

[48] Sekaran, Uma. (2003). Research Methods For Business A Skill- Building Approach. USA : John Wiley and Sons.

[49] Skakon, J., Nielsen, K., Borg, V. and Guzman, J. (2010). Are leaders' well-being, behaviours and style associated with the affective well-being of their employees? A systematic review of three decades of research. Work and Stress, 24(2), 107139.

[50] SUPRIYANTO, A. S., SUJIANTO, A. E., \& EKOWATI, V. M. (2020). Factors Affecting Innovative Work Behavior: Mediating Role of Knowledge Sharing and Job Crafting. The Journal of Asian Finance, Economics and Business, 7(11) 999-1007. doi:10.13106/jafeb.2020.vol7.no11.999

[51] Tepper, B. J. (2000). CONSEQUENCES OF ABUSIVE SUPERVISION. Academy of Management Journal, 43(2), 178-190. doi:10.2307/1556375

[52] Thien, L. M. (2019). Distributive Leadership Functions, Readiness for Change, and Teachers' Affective Commitment to Change: A Partial Least Squares Analysis. SAGE Open, 9(2), 215824401984620. doi:10.1177/2158244019846209

[53] Ugaddan, R. G., \& Park, S. M. (2017). Quality of leadership and public service motivation. International Journal of Public Sector Management, 30(3), 270-285. doi:10.1108/ijpsm-082016-0133

[54] Ybema, J. F., Smulders, P. G. W., \& Bongers, P. M. (2010). Antecedents and consequences of employee absenteeism: $A$ longitudinal perspective on the role of job satisfaction and burnout. European Journal of Work and Organizational Psychology, 19(1), doi:10.1080/13594320902793691
102-124. 